\title{
Performance of Banana cv. Grand Naine (AAA) for Direct Bunch Feeding of Major and Micronutrients on Bunch Yield
}

\author{
Venkata Rao* and G.S.K. Swamy \\ Department of Fruit Science, College of Horticulture, Mysore-571 130, University of \\ Horticultural Sciences, Bagalkot, Karnataka, India \\ *Corresponding author
}

A B S T R A C T

Keywords

Banana, Bunch feeding, Major and micronutrients, Grand Naine and Yield.

Article Info

Accepted:

12 September 2017

Available Online:

10 November 2017
Performance of banana for the direct feeding of major and micronutrients directly to the cut end stalk of bunch was studied at College of Horticulture, Mysore in tissue culture plants of 'Grand Naine (AAA)' banana having uniform sized bunches. The experiment was conducted in the year 2015-16 and 2016-17. The results of the investigation revealed that the Treatment $\mathrm{T} 7$ (5g Urea $+5 \mathrm{~g}$ SOP $+5 \mathrm{~g}$ Banana Special $+500 \mathrm{~g}$ Cow dung $+200 \mathrm{~mL}$ Water) was found superior compared to other treatments with respect to finger weight and bunch weight (180.30g and $30.91 \mathrm{~kg}$ respectively) and it is on par with treatment $\mathrm{T} 8$ (10g Urea + $10 \mathrm{~g}$ SOP $+7.5 \mathrm{~g}$ Banana Special $+500 \mathrm{~g}$ Cow dung $+200 \mathrm{ml}$ Water $)(169.29 \mathrm{~g}$ and $30.13 \mathrm{~kg}$ respectively). The increase in finger weight is $38.35 \mathrm{~g}$ (T7) in comparison with the treatment control similarly the increase in bunch weight is $6.23 \mathrm{~kg}$ (T7) in comparison with control.

\section{Introduction}

Nutrients play a significant role in production of high yield of good quality fruits. Providing appropriate quantities of nutrients in the right proportion when needed most is the essence of management of nutrients in successful banana cultivation. Banana (Musa sps) is one of the major commercial fruit crops of many tropical and subtropical regions of India. It is cultivated in an area of 841.0 thousand ha with production of 29135.0 thousand MT and productivity of 35.6 $\mathrm{MTha}^{-1}$ (Annon, 2015). Banana is a nutrient loving crop especially potassium and micronutrients and high potassium availability is important at fruiting stage. Any limitation in the supply of nutrients at the shooting stage affects bunch size and quality in banana. Among the several factors affecting fruit quality, adequate nutrients specially nitrogen and potassium application is considered to be of utmost importance in banana cultivation. Potassium is known to influence fruit yield in general and fruit quality in particular (Tandon and Sekhon, 1988). Translocation of nutrients in the infructescence of banana cvs. Poovan, Monthan and Nendran has been reported by various scientists (Buragohain and Shanmugavelu, 1985; Sobhana and Aravindakshan, 1989). The beneficial effects of late application of fertilizer are evident 
from these experiments. In the present study, the potential impact of placement of Urea, SOP and Micronutrients consortium "Banana special" developed by Indian Institute of Horticultural Research, Bangalore at the cut stalk end on yield and yield attributes in banana cv. Grand Naine, the most important and the commercial cultivar of India was investigated. The objective of the study was to standardise the optimum dose of urea, SOP and Micronutrients consortium "Banana special" so as to get maximum output with minimum inputs.

\section{Materials and Methods}

The investigation on "Performance of Banana cv. Grand Naine for direct bunch feeding of major and micronutrients on bunch yield" was carried out during 2014-2015 and 2015-2016 at College of Horticulture, Mysore, University of Horticultural Sciences, Baglkot, Karnataka. The experiment was laid out on Randomized block design with eleven treatments and three replications. The spacing adopted was $1.8 \times 1.8$ $\mathrm{m}$. The methodology involves de-navelling the stalk of the distal / lower end of the banana bunch after the bunch formation when $7-8$ petals of the flower are shed, by cutting the stalk at $60^{\circ}$ angle with a sharp knife keeping about $15 \mathrm{~cm}$ long stalk to receive the treatment. Preparing cow dung slurry in a used milk plastic bag or 200guage $15 \mathrm{~cm}$ x 25 $\mathrm{cm}$ plastic bags by blending $500 \mathrm{~g}$ fresh cow dung in $200 \mathrm{ml}$ of water with nutrients. Tie the plastic bag containing the slurry of cow dung suitably enriched to the de-navelled distal end of the stalk of the banana bunch with a strong thread in such a way that about $8-10 \mathrm{~cm}$ of the de-navelled end is immersed in the slurry. The treatments involves $\mathrm{T}_{1}-5 \mathrm{~g}$ Banana Special $+500 \mathrm{~g}$ Cow dung $+200 \mathrm{ml}$ Water, $\mathrm{T}_{2-}$ $7.5 \mathrm{~g}$ Banana Special $+500 \mathrm{~g}$ Cow dung + $200 \mathrm{ml} \mathrm{Water,} \mathrm{T}_{3}-10 \mathrm{~g}$ Banana Special $+500 \mathrm{~g}$ Cow dung $+200 \mathrm{ml}$ Water, $\mathrm{T}_{4}-5 \mathrm{~g}$ Urea $+5 \mathrm{~g}$ $\mathrm{SOP}+500 \mathrm{~g}$ Cow dung $+200 \mathrm{ml}$ Water, $\mathrm{T}_{5^{-}}$ $10 \mathrm{~g}$ Urea $+10 \mathrm{~g}$ SOP $+500 \mathrm{~g}$ Cow dung +
$200 \mathrm{ml}$ Water, $\mathrm{T}_{6}-15 \mathrm{~g}$ Urea $+15 \mathrm{~g}$ SOP + $500 \mathrm{~g}$ Cow dung $+200 \mathrm{ml} \mathrm{Water,} \mathrm{T}_{7}-5 \mathrm{~g}$ Urea + $5 \mathrm{~g}$ SOP $+5 \mathrm{~g}$ Banana Special $+500 \mathrm{~g}$ Cow dung $+200 \mathrm{ml}$ Water, $\mathrm{T}_{8-} 10 \mathrm{~g}$ Urea $+10 \mathrm{~g}$ SOP +7.5 g Banana Special $+500 \mathrm{~g}$ Cow dung $+200 \mathrm{ml}$ Water, $\mathrm{T}_{9}-15 \mathrm{~g}$ Urea $+15 \mathrm{~g}$ SOP $+10 \mathrm{~g}$ Banana Special $+500 \mathrm{~g}$ Cow dung $+200 \mathrm{ml}$ Water, $\mathrm{T}_{10}-500 \mathrm{~g}$ Cow dung $+200 \mathrm{ml}$ Water and $\mathrm{T}_{11}$-Control. Observations on bunch characters especially the finger weight and bunch weight were recorded. The data was subjected to statistical analysis following standard procedures (Panse and Sukhatme, 1989).

\section{Results and Discussion}

Due to the application of different types of nutrients combined with fresh cowdung as bunch feeding, a marked effect on fruit and bunch weight was observed in the present investigation.

\section{Finger weight}

The data in Table 1 (Fig. 1) showed that the finger weight varied significantly in different treatments, The pooled data shows that the treatment $\mathrm{T}_{7}(5 \mathrm{~g}$ Urea $+5 \mathrm{~g} \mathrm{SOP}+5 \mathrm{~g}$ Banana Special $+500 \mathrm{~g}$ Cow dung $+200 \mathrm{ml}$ Water) found to be having highest finger weight of $180.39 \mathrm{~g}$ followed by the treatment $\mathrm{T}_{2}(7.5 \mathrm{~g}$ Banana Special $+500 \mathrm{~g}$ Cow dung $+200 \mathrm{ml}$ Water) and $\mathrm{T}_{8^{-}} 10 \mathrm{~g}$ Urea $+10 \mathrm{~g} \mathrm{SOP}+7.5 \mathrm{~g}$ Banana Special $+500 \mathrm{~g}$ Cow dung $+200 \mathrm{ml}$ Water) which had a finger weight of $170.87 \mathrm{~g}$. The banana finger with lowest finger weight $(141.09 \mathrm{~g})$ was found in the treatment $\mathrm{T}_{10}$ (500g Cow dung $+200 \mathrm{ml}$ Water). The treatments above $10 \mathrm{~g}$ showed blackening and burning of the terminal fingers and hand which were more proximal to the treatment. The results are in conformity with Shira et al., (2012) and Rhman et al., (2014) who found that the bunch feeding with nutrients and cowdung has significant effect on finger as well as bunch weight. 
Table.1 Effect of direct feeding of nutrient to banana bunch on finger weight

\begin{tabular}{|c|c|c|c|}
\hline \multirow{2}{*}{ Treatments } & \multicolumn{3}{|c|}{ Finger Weight $(\mathbf{g})$} \\
\cline { 2 - 4 } & $\mathbf{2 0 1 5 - 1 6}$ & $\mathbf{2 0 1 6 - 1 7}$ & Pooled \\
\hline T1 & 145.96 & 216.15 & 162.92 \\
\hline T2 & 149.79 & 236.15 & 170.87 \\
\hline T3 & 162.54 & 199.68 & 160.74 \\
\hline T4 & 166.45 & 197.90 & 164.78 \\
\hline T5 & 140.54 & 229.55 & 168.92 \\
\hline T6 & 145.00 & 198.81 & 147.93 \\
\hline T7 & 159.54 & 234.98 & 180.39 \\
\hline T8 & 164.46 & 213.41 & 169.29 \\
\hline T9 & 134.66 & 205.95 & 146.87 \\
\hline T10 & 134.39 & 188.90 & 141.09 \\
\hline T11 & 143.85 & 192.28 & 142.04 \\
\hline CV & 11.97 & 8.16 & 6.92 \\
\hline CD@5\% & 24.32 & 29.23 & 18.82 \\
\hline
\end{tabular}

Table.2 Effect of direct feeding of nutrient to banana bunch on bunch weight

\begin{tabular}{|c|c|c|c|}
\hline Treatments & \multicolumn{3}{|c|}{ Bunch Weight $(\mathbf{k g})$} \\
\hline & $\mathbf{2 0 1 5 - 1 6}$ & $\mathbf{2 0 1 6 - 1 7}$ & Pooled \\
\hline T1 & 27.66 & 31.60 & 26.87 \\
\hline T2 & 27.50 & 32.32 & 27.28 \\
\hline T3 & 29.60 & 31.90 & 27.31 \\
\hline T4 & 29.16 & 31.77 & 28.20 \\
\hline T5 & 26.26 & 35.18 & 28.73 \\
\hline T6 & 23.33 & 33.20 & 25.52 \\
\hline T7 & 30.80 & 36.90 & 30.91 \\
\hline T8 & 32.23 & 33.70 & 30.13 \\
\hline T9 & 23.60 & 31.83 & 24.90 \\
\hline T10 & 23.50 & 30.25 & 24.95 \\
\hline T11 & 23.03 & 30.75 & 24.68 \\
\hline CV & 4.11 & 7.04 & 6.01 \\
\hline CD @5\% & 1.88 & 2.92 & 2.78 \\
\hline
\end{tabular}


Fig.1 Graphical representation of variations in the weight of finger and bunch

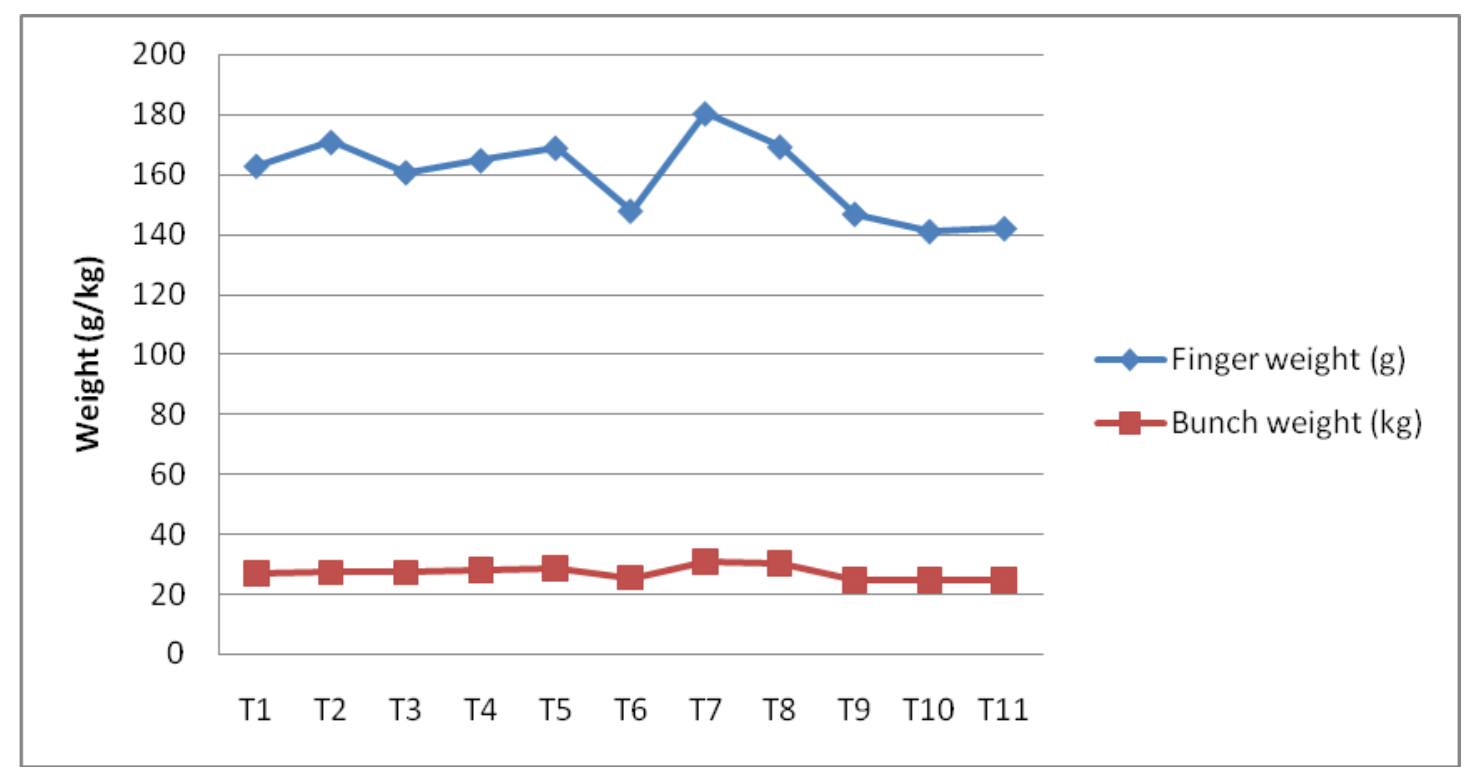

\section{Bunch weight}

The data in relation to the bunch weight is presented in Table 2 (Fig. 1). The results shows that the treatment $\mathrm{T}_{7}(5 \mathrm{~g}$ Urea $+5 \mathrm{~g}$ $\mathrm{SOP}+5 \mathrm{~g}$ Banana Special $+500 \mathrm{~g}$ Cow dung $+200 \mathrm{ml}$ Water) recorded the highest bunch weight of $30.91 \mathrm{~kg}$ followed by the treatment $\mathrm{T}_{8}(10 \mathrm{~g}$ Urea $+10 \mathrm{~g}$ SOP $+7.5 \mathrm{~g}$ Banana Special $+500 \mathrm{~g}$ Cow dung $+200 \mathrm{ml}$ Water) which had a bunch weight of $30.13 \mathrm{~kg}$. The minimum bunch weight of $24.68 \mathrm{~kg}$ was found in the treatment $\mathrm{T}_{11}$ (Control). The results clearly indicate that there is a significant difference in the weight of fingers as well as bunches which were treated with the major as well as micronutrients along with the fresh cowdung when compared to the untreated bunches. Similar findings were reported by Dutta and Banik (2007), Deependra et al., (2014) and Kotur and Murthy (2010).

In spite of feeding the banana plants with recommended quantities of major and micronutrients either through soil or by foliar application, the uptake and utilization of nutrients by banana plants is inadequate resulting in poor growth of bunch and fingers of the banana in the bunch. Particularly the fingers at the distal end of the bunch remain poorly developed owing to an adverse competition of the top hands with those located at the lower end of the bunch. This reduces both the total weight as well as its overall appearance leading to a lower profitability. This has been a major constraint faced by the banana growers irrespective of the variety of banana grown. Hence, the present investigation shows the banana bunch weight can be enhanced by the direct feeding of nutrients to the bunch.

\section{References}

Anonymous, 2015. Banana. Indian Hort. Database, National Horticulture Board, Ministry of Agriculture, Govt. of India, Gurgaon.

Buragohain, R. and Shanmugavelu, K.G., 1985. A study on the translocation of plant nutrients from the sink towards the source in certain banana cutlivars using ${ }^{32}$ P. Banana Newslett. 8, 31-33.

Deependra yadav, Singh S.P. and Sarvesh Singh. 2014. Effect of foliar application of potassium compounds on yield and 
quality of ber (Zizyphus mauritiana lam.) cv. Banarasi karaka. International Journal of Research in Applied, Natural and Social Sciences. 2(2): 89-92.

Dutta, P. and Bauik, A.K. 2007. Effect of foliar feeding of nutrients and plant growth regulators on physico- chemical quality of sardar guava grown in red and lateritic tract of west Bengal. Acta Horticulture. (735):407-411.

Kotur, S.C. and Keshava Murthy, S.V. 2010. Enhancing fruit yield in Ney Poovan banana (Musa paradisiaca L.) by denavelling and feeding $\mathrm{N}, \mathrm{K}$ and $\mathrm{S}$ though distal stalk end of the bunch. Journal of Horticulture Science.5 (1):53-56.

Panse, V.K. and Sukhatme, P.V. 1989. Statistical methods for agricultural workers. ICAR, New Delhi (INDIA).

Rhman, I.E.A.E. and Shadia. A.A. 2014. Effect of foliar sprays of urea and zinc on yield and physico-chemical composition on Jujube (Ziziphus mauritiana). Middle East Journal of Agriculture Research, 1(1): 52-57.

Shira, V.D., Bauri, F.K., Sarkar, S.K. and Uchoi, J. 2012. Bunch management technique for improving yield and quality of Martaman (AAB) banana. Plant Archives. 12 (2): 875-878.

Sobhana, A. and Aravindakshan, M., 1989. Translocation of phosphorus in banana after shooting. J. Nuclear Agric. Biol. 18(4), 243-245.

Tandon, H. L. S. and Sekhon, G. S. 1988. Potassium Research and Agricultural Production in India. CAB Direct.

\section{How to cite this article:}

Venkata Rao and Swamy, G.S.K. 2017. Performance of Banana cv. Grand Naine (AAA) for Direct Bunch Feeding of Major and Micronutrients on Bunch Yield. Int.J.Curr.Microbiol.App.Sci. 6(11): 1577-1581. doi: https://doi.org/10.20546/ijcmas.2017.611.189 